\title{
RESEARCH OF THE CORRELATION BETWEEN EDUCATION AND ECONOMIC GROWTH (THE
} CASE OF ISRAEL \& MOLDOVA)

CROTENCO Irina,

$\mathrm{PhD}$ in Economics, Free International University of Moldova

MASRI Bushra, Israel, PhD student, Free International University of Moldova rard@walla.co.il

\section{SUMMARY}

The education and training of the labor force in the country are the most important and significant factors in developing the economic future of any country. This article will try to describe the connection between these two terms, which are interesting to many governments in developed and developing countries. Is presented the analysis of economic data in connection to the educational field in both Israel and Moldova. Are presented conclusions and recommendations on the problem.

Key words: Higher Education, Economic Growth, Employment Rate, Globalization, Workforce Training.

\section{CERCETAREA CORELAȚIEI ÎNTRE EDUCAȚIE ȘI CREȘTERE ECONOMICĂ (CAZUL ISRAELULUI ȘI MOLDOVEI)}


CROTENCO Irina,

Dr. în economie,

Universitatea Liberă Internațională din Moldova

MASRI Bushra,

Israel, doctorandă,

Universitatea Liberă Internațională din Moldova

rard@walla.co.il

\section{REZUMAT}

Educația și formarea forței de muncă din țară sunt cei mai importanţi și semnificativi factori în dezvoltarea viitorului economic al oricărei țări. Acest articol va încerca să descrie legătura dintre acești doi termeni, care sunt interesanți pentru multe guverne din țările dezvoltate și în curs de dezvoltare. Este prezentată analiza datelor economice în legătură cu domeniul educaţional atât în Israel, cât și în Moldova. Sunt prezentate concluzii și recomandări cu privire la problemă.

Cuvinte-cheie: învățământ superior, creștere economică, rată de ocupare a forței de muncă, globalizare, formare a forței de muncă.

Introduction. Globalization and international trade between countries and industrial regions are causing competition among the various economies in the world. Some of the developed countries that are financially successful as a result of competitive advantage over other economies. As is well known, a typical economy in a developed country will include a variety of different industries with different competitive advantages and disadvantages in the global market. The education and training of the country's workforce is the most important and significant factor in developing the economic future of any country.

Many states and governments may try to incentivize workers' training and education through various tax incentives and economic incentives, providing a learning environment and professional content for effective and modern employee training, and a variety of other measures designed to create more skilled workforce and business frameworks. As is well known, it does not make sense for any economy to gain a competitive edge in all industries, but it can focus on a number of industries where skilled professionals create the competitive advantage that is good for them and the government [19].

Materials. The differences in rank and quality of education create a significant difference between developed countries and countries that are only in their economic development stage. Although there are other factors that make the difference, such as: geographical location, natural treasures, financial capital and international contacts, there are also differences in the quality of the workforce that are better trained, have a culture of labor and positive inner motivation. External factors can have a positive impact on economics due to the well-trained personnel. From another point of view, countries and business-economic companies benefit by having professional and skilled personnel capable of carrying out the work required. Countries are also aware that this workforce may be located in certain geographies and has an advantage over local populations. For example, Israel "imports" skilled manpower in construction from Moldova and Ukraine. As a result, similar businesses may cluster in the same geographic area because of the same skilled workers.

According to Dahn and Hazan [3], the basic conditions for economic success in developed and developing countries will be based on much defined steps:

A. Knowledge, self - intelligent, education, experience and interpersonal skills of employees from the job supply is a crucial factor for both business and economic growth. It is known that.

$B$. Industries with higher education requirements will intend to pay for the workers higher wages.

C. The differences in training levels, and the quality of skills imparted to the employee, are a significant factor separating developed and developing countries.

D. The output of the economy and GDP will increase, as the number of educated workers increases as skilled workers can be perform tasks more efficiently.

The connection between rate of employment and higher education in Israel. According to BOI - bank of Israel [2], in economic terms, acquiring education is a financial investment, and the expected level of income over a lifetime is the expected profit. Measuring the relative income of working-age people in Israel, by education levels, therefore provides important information about the relationship between the higher education system and the employment market in Israel. Workers in level of ages by 64-15 are employed by education levels, for 2019.

The State of Israel, compared to the OECD countries with academic education, enjoy higher incomes from their work, compared to those with lower education levels. In Israel, the situation is that an academic will earn $51 \%$ more than those who graduated from high school and did not go on to graduate school and about $80 \%$ more than those who did not finish high school. In the Scandinavian and New Zealand countries, these gaps are lower among the OECD countries. Particularly high gaps were measured in Brazil and Hungary. The next figure (figure 1) will describe the relationship between two main terms - GDP - Gross Domestic Product which measures the value of economic activity within a country. Strictly defined, GDP is the sum of the market values, or prices, of all final goods and services produced in an economy during a period of time, and the employment rate which measures the percent of Israeli workers in the state. 


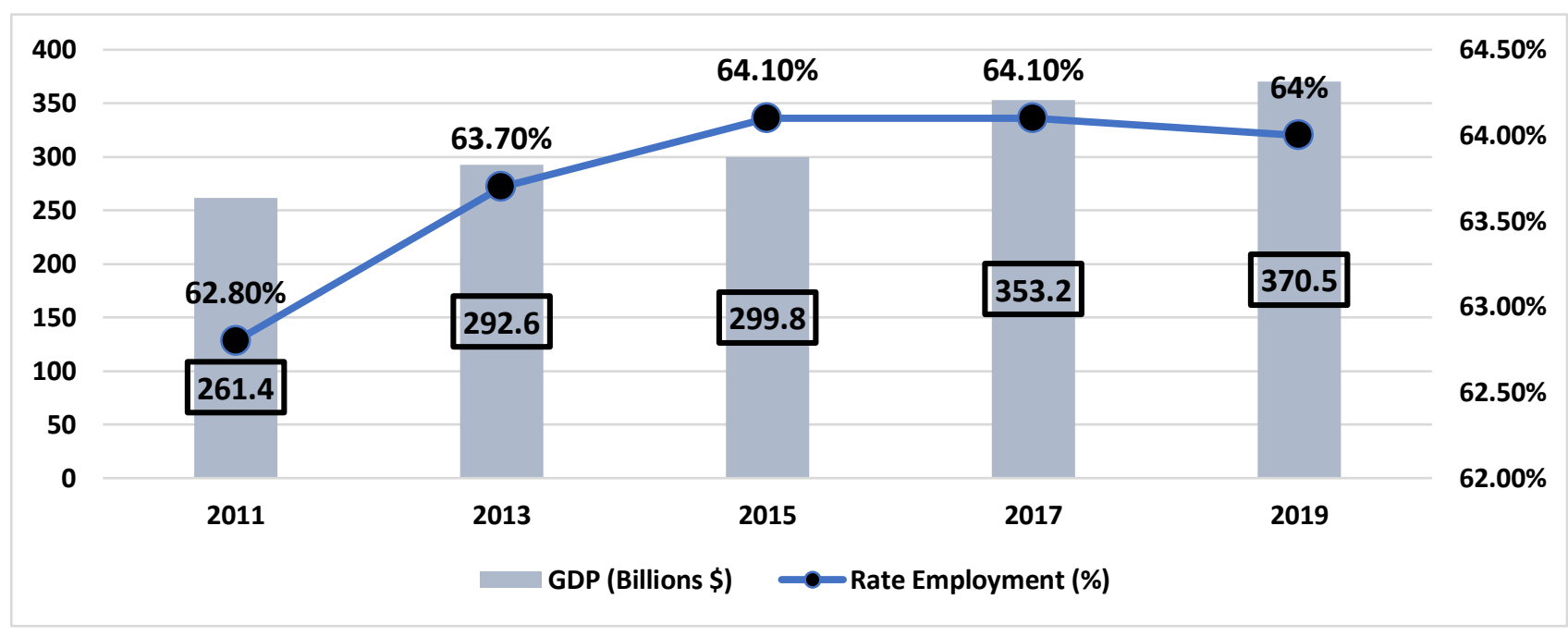

Figure 1. Rate of Employment (\%) compared to GDP growth (Billions USD) in Israel, 2011 - 2019

Source: made by the author based on $[1,7,12]$

The author found that according to figure 1, there is direct correlation between the numbers of the employment rate to the growing of the GDP. There is no doubt that the more the Israeli economy provides employment, the higher the contribution to the economy, and the higher the value of GDP. The economic-fiscal strategy is that the creation of jobs, local industry, contributes to the economy and to the domestic product.

The next figure (figure 2) will describe another option of potential correlation, the employment rate and the numbers of Israeli higher education students.

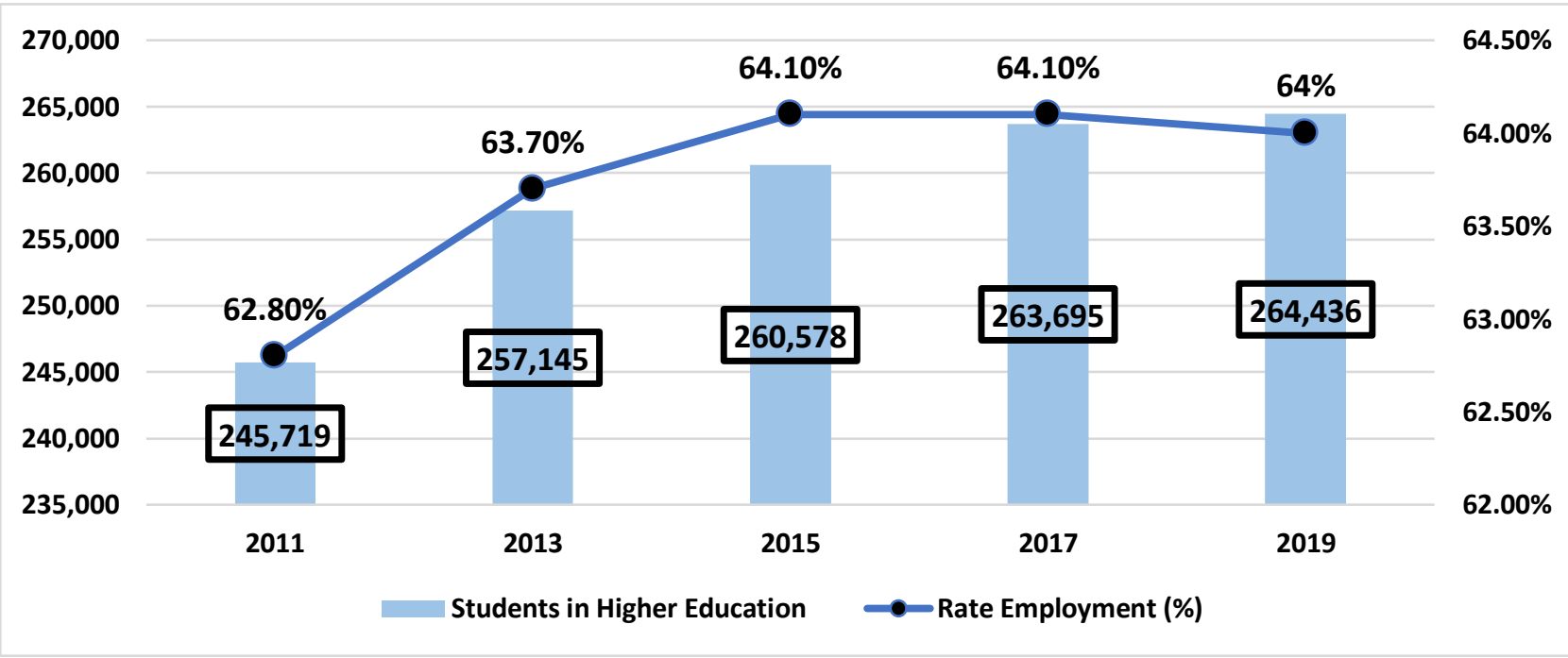

Figure 2. Rate of employment (\%) compared to Israeli higher education students, $2011-2019$

Source: made by the author based on $[1,7,12]$

At this figure, the author found also a direct correlation between the numbers and the percent. We have seen a modest increase in the number of students $(20,000)$ between 2011 and 2019. At the same time, there is little growth in the percentage of employees, but the numbers are still positive on a scale to the OECD.

Academics graduating from universities and colleges earn more than twice as high school graduates and even more as employed persons who did not graduate from high school - according to a joint study by the Taub 86
Center, led by Bin - Nun [2], and the Bank of Israel [1]. The results of this study were presented at an international conference in April 2019. Further studies presented also reveal that the level of schooling and the scope of core studies contribute significantly to economic growth, so that low investment in the education system and neglecting core studies impairs economic growth. According to the Taub Center's study, there is a close relationship between the level of education and employment and income among the main working age in 
Israel - similar findings to the OECD's annual education report released last week. Of course, these figures contribute to the level of the country's economy and the government's fiscal policy in Israel. According to the findings, $63 \%$ of the working-age population who purchased up to eight years of education alone are not employed. The employment rate does not fall to $42 \%$ among $10-9$-year-olds and $27 \%$ to $12-11$-year-olds. In academics, the employment rate is the lowest - $13 \%$. These findings present an economic picture:

1. The level of income of academics is also the highest - on average NIS 11,857 - more than twice that of employees who have purchased 10-9 years of schooling - NIS 5,535, employees who have completed 12-11 years of study earn an average of NIS 6,611 a month. The lowest income is among employed persons who have not completed 8 years of schooling and amounts to an average of only 4,827 .

2. According to the study, only $31 \%$ of the main employment age group (54-25) have a college degree, but the education of almost half of the population - $45 \%$ amounts to less than 12 years of schooling, and therefore a significantly lower salary.

Comparison between Israel and the United States - According to a study by University of Chicago professor Even [4], research findings are consistent with findings in other states. In the United States, each additional academic year contributes $8 \%$ to $15 \%$ of work income and four years of college education. Work income about $65 \%$. According to research conducted at the conference, in countries that invest more in human capital development through education through education, the growth rate is higher.

The connection between employment rate and Moldavian GDP.

In early of 2017, some changes and reforms were made in the public sector in Moldova. As part of the change, it was decided to reduce the number of government offices from 16 offices to 9 government offices. Offices such as the Ministry of National Education, and the ministry responsible for social protection and family, have been re-established by merging them with other offices in the overall administration. In addition, it was decided to establish two new offices: The Ministry of Labor, Health and Social Protection (MoLHSP) and a professional change in the Ministry of Education, Culture and Research (MoECR).

The reform broad idea is also included a focus on professional choice in the work process that included careful scrutiny of the professional in the process of selecting staff, controlling and controlling the financial increases of all government ministries, giving public office more efficiently and increasing the financial motivation of civil servants.

With no other choice, fewer recruits and higher salaries are expected to streamline public service. The restructuring of national institutions, various government ministries, and a comprehensive workforce within all state institutions continued into 2018 and included the National Employment Agency (NEA), a labor market reform consultancy, the Quality Assurance Agency, and the Center for the Implementation of Education Policy and Vocational Training.

We must internalize, but the Republic of Moldova is a small, low-middle-income economy with a pretty high share of classic industry that includes basic factory of agriculture, and only essential services. In Moldova, there is also an uneven territorial division of economic opportunity and growth, with the capital, Chisinau, producing more than half of GDP, and other regions in Moldova receiving less investment, infrastructure and, of course, economic - employment opportunities. The main economic activity that generates revenue from GDP is industry (with food products accounting for about $37 \%$ of GDP), trade, agriculture, construction and transport, as well as information and communication technologies and services.

After the economic recession of 2015 (not least because of the large-scale banking scams that occurred in Moldova), Moldova's economy rebounded, and as of 2017, GDP growth was a minimum of $4.5 \%$ each year. These positive data came as a result of good performance in agriculture, when a good crop led to growth of $12.7 \%$ of exports, as well, due to overall growth and reform of commercial services rendered, private consumption also contributed to GDP growth, increasing 4.9\% in 2018. This economic growth is driven by remittances, strong growth in wages and linkage of public transfers in 2017. Growth The economic which was expected to be good in 2018 reached $3.8 \%$

And $3.7 \%$ in 2019 , which is still below the historic average of $4.6 \%$. When the economic outlook for the initial scenario is subject to considerable external and internal risks, further structural reforms are still needed to grow the private sector and create jobs for the general public that does not work but is created in the overall workforce. In recent years, the new government has taken steps to improve the business climate and Moldova has risen in several places (in the global table) in the World Economic Forum's World Competitiveness Report 2019 (ranked 89 out of 137 participating countries). The government stepped up the implementation of the reforms and decided on:

1. Developing and upgrading public services provided to citizens and external investors;

2. Opening the commercial market and transitioning to the liberalization of the economy in Moldova;

3. Developing the financial system to create a positive investment climate by providing incentives and tax relief to investors;

4. Promoting and supporting the development of SMEs;

5. In-depth reform of the judiciary and eradication of corruption in the public sector;

6. Improving public transport and other physical infrastructure;

7. Diversity and promotion of exports, and support of exporters.

The national parliamentary elections held in February 2019 affected the level of investor confidence in the medium term. Although income inequality, reflected in the Gini coefficient, improved from $32.2 \%$ in 2014 to $37.3 \%$ in 2018 , Moldova remains one of the poorest 
countries in Europe, with a per capita GDP of only \$ 5,343 (US dollars) provided parity. The following figure will show the employment rate (\%) compared to GDP growth (billions of dollars) in Moldova from 2011 -
2019.

The following figure (3) will present the rate employment which compare to the GDP growth.

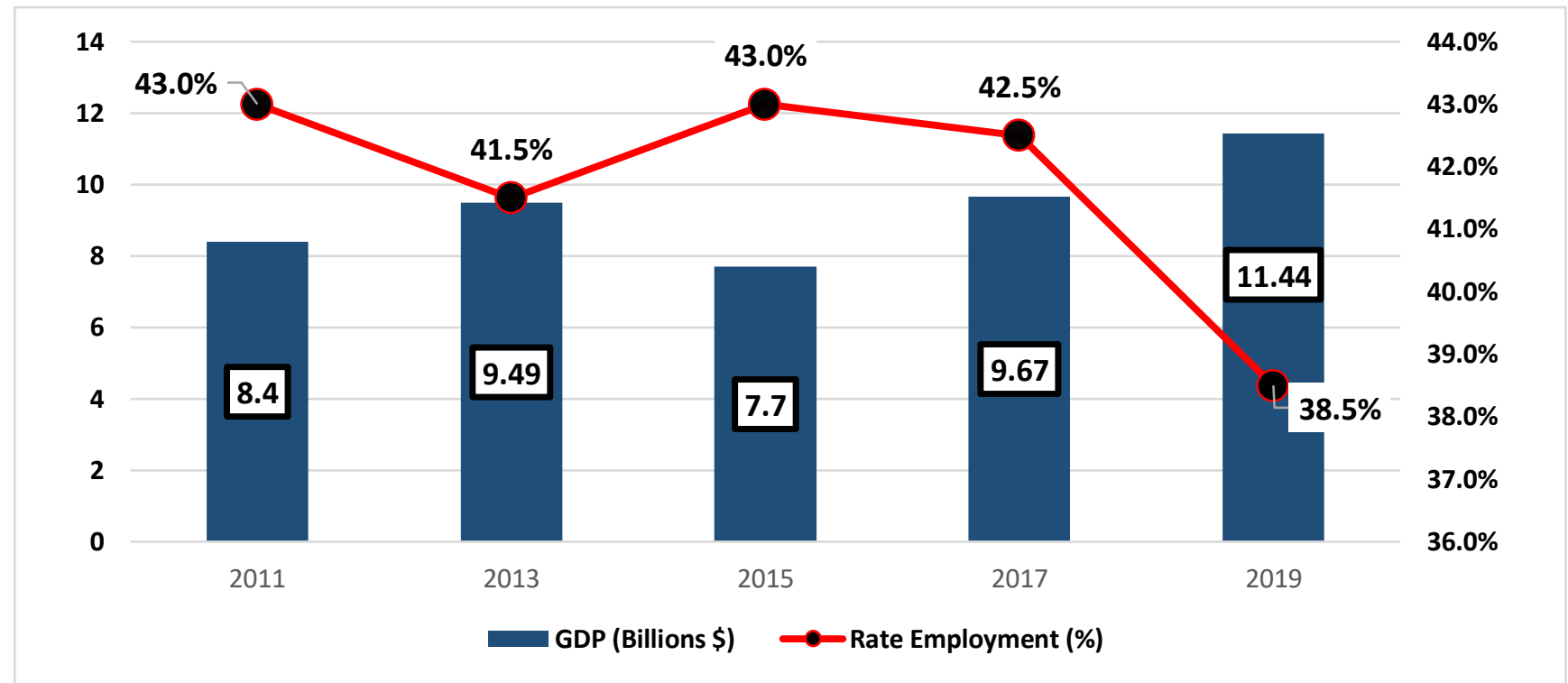

Figure 3. Rate of Employment (\%) compared to GDP growth (Billions USD)

in Moldova, 2011 - 2019

Source: made by the author based on $[16,17]$

As we will see, the author of an article identifies a relationship between the percentage of employed and the contribution to GDP growth. The writer recognizes a jump in 2011 through 2015 and the results come right afterwards with a significant jump in subsequent years.

Today, Moldova has faces with a problematic, complex and challenging employment reality. The employment-economic situation offers unsatisfactory jobs (quantity of jobs) and no quality (employment jobs for academics). The data describe a low throughput, constant informal arrangements and employment inequality. The country's labor market is characterized by low activity and employment rates $(42.2 \%$ and $40.5 \%$ respectively in 2017), with no significant gender disparities between women and men, and age differences. However, there are huge differences in employment by educational attainment, with a 28.2 percentage point gap between the high and low skilled (56\% and 27.8\% respectively).

In the Republic of Moldova, the low cumulative unemployment rate stood at $4.1 \%$ in 2018 . This can be attributed to both a very low activity rate and outward migration (brain drain), as well as the specific definition of inactivity in the Moldova Labor Force Survey (LFS) that could Distort. The overall picture. In particular, if a household member is absent during the survey because he is abroad, that person is listed as 'inactive'. Moldovan immigrants currently working abroad are therefore considered "residents" for the LFS purposes and are considered to be an inactive population as well as a reference population. 15 and over. When LFS results are recalculated, excluding this category from the sample, the 2016 activity rate among the $15+$ population increases from $42.6 \%$ to $47.7 \%$, and the employment rate from
$40.8 \%$ to $45.7 \%$.

According to Weede [18], a new National Employment Strategy for 2020 was adopted in March 2017, and enacted the New Employment Promotion Law, which was approved in June 2018 and came into force in February 2019. The government in Moldova has also adapted its regulatory framework for small and mediumsized businesses and employers (an organization which called SME), with a stronger emphasis on female entrepreneurship and green economics. Adopting the Social Entrepreneurship Act in November 2017 is another economic idea - another important development. In July 2018, the World Bank approved a renewed \$ 30 million economic governance development policy for Moldova, which will support a wide range of important structural reforms.

While Moldova has increased its ability to absorb external aid and is currently attracting investors who see it as an upgraded economic potential, its reforms must be closely monitored. Aligning the education system (with a focus on higher education, and vocational education), with the needs of the labor market to improve labor output and increase employment, which remains a key issue on the government's agenda. As noted, there is a special emphasis on higher education and vocational education and training (VET); Modernization of education and training systems; Improving quality, relevance and approach; And establishing the National Qualifications Framework (NQF). In 2017, the government adopted several legal actions on education and training. The following figure (figure 4) will present the employment rent of the labor force, compare to the Moldavian higher education. 


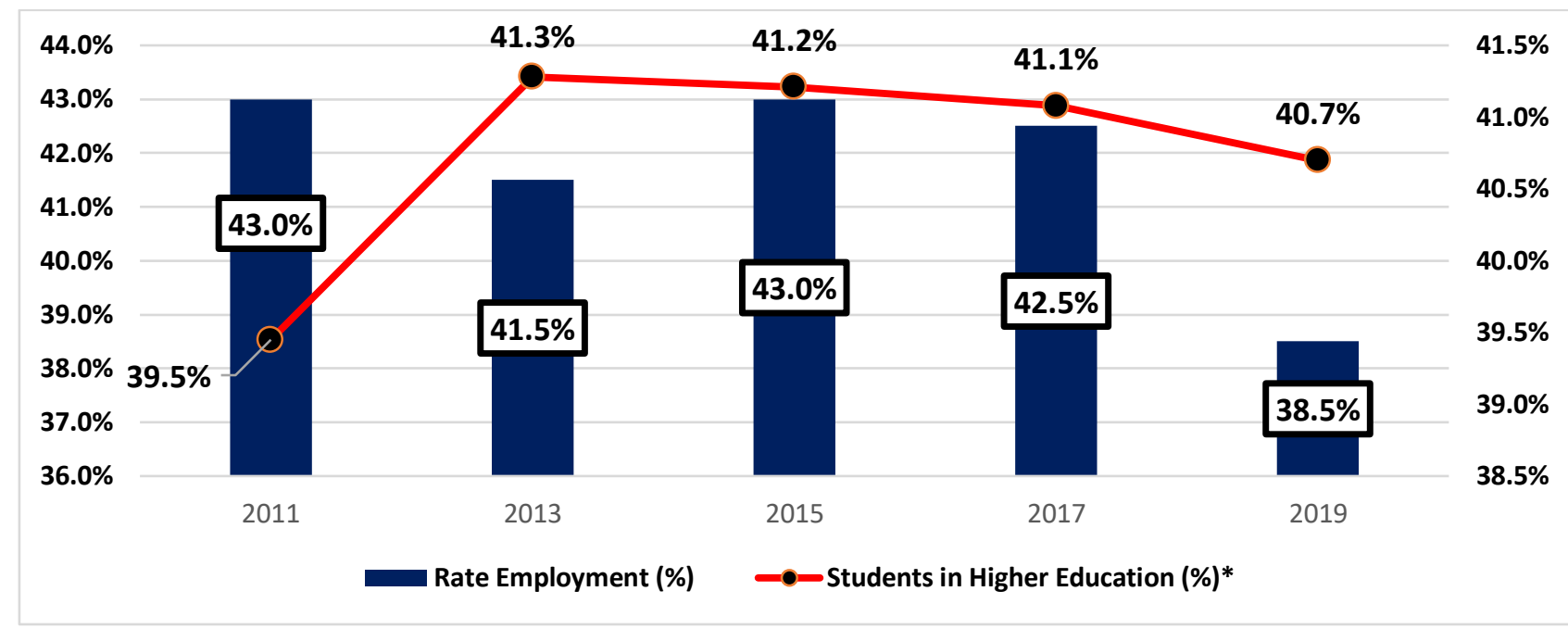

Figure 4. Rate of employment (\%) compared to Moldavian higher education students, 2011 - 2019

Source: made by the author based on $[16,17]$

The analysis of the data and graphs shows that even in this case, like Israel's data assessment, we find that there is a direct relationship between the investment in academic education that grows from students and employment and the growth of GDP. The author of the article concludes that the strategic analysis of the success of the Israeli economy is similar in its context to the Moldavian economy. Although there are indeed growing gaps between the GDP of Israel and Moldova, we find that there is a need for industrial change in Moldova (increased investment in advanced industry over traditional industry and agriculture).
Conclusions. To conclude, the research showed us that the State of Israel and the Republic of Moldova have many similar characteristics. Both countries, each for its causes and economic history - demographic - cultural economic - are currently in a time of economic and social crisis. The brain drain and academic mobility cause economic changes in the structure of labor force. Only national investment and motivation for economicemployment success will have a positive impact that will be reflected in the increase in the economic prosperity of each country.

Bibliographic references:

1. Bank of Israel. Series Data Base, Jerusalem, 2019. http://www.bankisrael.gov.il/series/en/ (Date of visit: 22.12.2020).

2. Bin - Nun, G. What can be learnt from international comparisons? Jerusalem: The State of Israel, 2018.78 -88 p. (In Hebrew).

3. Dahan M, Hazan M Priorities in the Israeli government's budget. 2018 http://public-policy. Huji .ac.il/upload/sidreiadifouiot.pdf (Date of visit: 4.12.2020).

4. Even, S. possible trends in the global oil and meanings strategies to Israel. Tel Aviv: Jaffe Center for Strategic Studies. 2017, 58 -63 p. (In Hebrew).

5. Farsakh, L. Palestinian Labour Migration to Israel: Labour, Land and Occupation. London: Routledge, Oxon. 2005, $28-29$ p.

6. IOM (International Organization for Migration) - 2017 Moldova - Migration and Remittances, Report by the International Organization for Migration, Moldova.

7. Israeli Economic - https://www.reuters.com/article/us-israel-economy-gdp-idUSKBN1YZ0SE (Date of visit: 15.12.20).

8. Lücke, M., et al. Patterns and trends of migration and remittances in Moldova. Geneva: International Organization for Migration. 2017, $155-159 \mathrm{p}$.

9. Ministry of Finance in Israel (MOF) - https://embassies.gov.il/san-francisco/AboutIsrael/ Economy/Pages/TheIsraeli-Economy-Today.aspx (Date of visit: 22.12.20).

10. Munteanu, A. Remittances and the governance deficit in Moldova: Remedies or sources of inequalities? Bucharest: South East Europe Review. 2016, 88 p.

11. OECD - Israel economy - http://oecdobserver.org/news/fullstory. php/aid/3544/A profile of the Israeli economy.html (Date of visit: 21.11.20).

12. OECD (2017), Economic Surveys: Israel, January.

13. OECD (2018), OECD Economic Outlook, No 89, May. www.oecd.org/israel

14. Pantiru, M. C., et al. Migration and poverty reduction in Moldova. Brighton: Working Paper C10, Development Research Centre on Migration, Globalization and Poverty. 19-22 p. 
15. The world bank - Israeli Data - https://data.worldbank.org/indicator/NY.GDP.MK TP.KD.ZG ?locations=IL-OEDE-US (Date of visit: 01.12.20).

16. The world bank - Moldavian Data - https://data.worldbank.org/indicator/NY.GDP.MKTP. KD .ZG?locations=MD (Date of visit: 01.12.20).

17. UNESCO - data of Moldova - http://uis.unesco.org/en/country/md (Date of visit: 22.09.20).

18. Weede, E. Capitalism, Democracy and Peace. In structure, Order and Disorder in World Politics, ed. Ulrike Schumacher. Peter Lang Pub Inc., Frankfurt, 2009- 616 .73 p.

19. Weizman, E. Hollow Land: Israel's Architecture of Occupation. London: Verso Books. 2007, 355 p. 